\title{
Has the Insulin Therapy Solved all Problems of Diabetes and its Complications?
}

\author{
Viktor Rosival* \\ Department of Laboratory Medicine, Dérer's Hospital, Limbová 5, SK-833 05 Bratislava, Slovakia, Europe
}

${ }^{*}$ Correspondence to: Viktor Rosival, SYNLAB, Department of Laboratory Medicine, Dérer's Hospital, Limbová 5, SK-833 05 Bratislava, Slovakia, Europe; E-mail: rosivalv@hotmail.com

Received: February 14, 2018; Accepted: February 23, 2018; Published: February 25, 2018;

\section{Perspective}

The recent case history of GREGORY and BASU [1] summarized in the title of the paper - has shown that nearly 100 years after the discovery of insulin and its introduction in the therapy are not solved all problems of diabetic complications. Immediately lifethreating are ketoacidotic coma and hyperosmolar hyperglycemic nonketotic coma.

Unfortunately, their "historical" development is marked by inattentiveness to important observations: already in 1886 has been reported coma in diabetic patients without "acetone or acetoacetic acid" in the urine [2]. Later, 1913, when it was already possible to measure concentration of hydrogen ion $\mathrm{H}+$ in the blood (= blood$\mathrm{pH})$, this fact has been confirmed [3]: among 11 comatose diabetic patients only 3 had acidosis (= low blood-pH). With other words, hyperosmolar hyperglycemic nonketotic coma has been reported already at the end of the 19 century and was the cause of majority of deaths in coma, however, it has been " accepted " only 1957 [4].

With the acceptance of its existence has aroused the problem how to explain the existence of two consequences of insulin deficiency. A very simple explanantion has been found: hyperosmolar hyperglycemic nonketotic coma is caused by decreased concentration of plasmatic insulin, ketoacidotic coma by absolute insulin deficiency. The Nobel prize 1977 to Rosalyn S. YALOW for developent of new methods of biochemical analysis that make it possible to measure insulin concenration in human plasma has denitively made clear that insulin does not participate in the pathogenesis of diabetic ketoacidosis: already in 1981 has been published the monograph „Diabetic coma: ketoacidotic and hyperosmolar“ [5]. There, on p 67 is the Figure 6.3 with names of 12 autors who have reported sufficient amounts of plasmatic insulin in patients with diabetic ketoacidosis. And absolute deficiency of plasmatic insulin has been reported in patients with coma in hyperosmolar hyperglycemic nonketotic state, eg [6].

Administration of insulin is a reliable prevention of of the hyperosmolar hyperglycemic nonketotic coma; today, it occurs seldom and insulin is also part of its successful treatment. Between 1990 an 2010 yearly 2000 - 3000 patients died in USA in diabetic ketoacidotic coma [7]. Thus, it remains to explain the cause of death in ketoacidotic coma, accompanied always with vey low blood-pH. 3 papers have shown and confirmed that low blood-pH is the cause of decreased level of consciousness and coma, and not only a harmless accompanying phenomenon [8-10]. This is the result of increased concentration of 36 organic acids [11], including also extreme acidosis without acetoacetic and beta-hydroxybutyric acids [12]. The glycolytic enzyme phosphofructokinase is $\mathrm{pH}$-dependent, as its activity is decreasing with decreasing $\mathrm{pH}$. Therefore, with decreasing blod-pH is decreased also the utilisation of glucose in brain cells. Increase and normalisation of the low blood-pH after infusions of alkalising solutions (such as sodium bicarbonate) is life-saving in comatose patients with diabetic ketoacidosis - zero lethality hs been reported with such treatment, e g [13].

The patient of GREGORY and BASU [1] is a further stone in the ineffectiveness of insulin therapy in diabetic ketoacidosis.

\section{References}

1. Gregory J, Basu S (2017) Diabetic ketoacidosis, hypeuricemia, and encephalopathy intractable to regular-dose insulin. Journal of Pediatric Endocrinology and Metabolism 30: 1317-1320. [Crossref]

2. Dreschfeld J (1886) The Bradshaw Lecture on Diabetic Coma. British Medical Journal 2: 358-363. [Crossref]

3. Rolly F (1913) Das Wesen und die Behandlung des Coma diabeticum. Medizinische Klinik15: 568-572

4. Sament S, Schwartz MB (1957) Severe diabetic stupor without ketosis. South African Medical Journal 31: 833-834. [Crossref]

5. Schade DS, Eaton RP, Alberti KGMM, Johnston DG (1981) Diabetic coma: ketoacidotic and hyperosmolar. University of New Mexico Press, Albuquerque, NM.

6. Vinik A, Seftel LT, Joffe BD (1975) Metabolic findings in hyperosmolar nonketotic diabetic stupor. Lancet 2: 45-46. [Crossref]

7. Gregg EW, Li Y, Wang J, Burrows NR, Ali MN, et al. (2014) Changes in diabetes - related complications in the United States 1990-2010. New England Journal of Medicine 370: 1514-1523. [Crossref]

8. Rosival V (1987) The influence of blood hydrogen ion concenration on the level of consciousness in diabetic ketoacidosis. Annals of Clinical Research 19: 23-25. [Crossref]

9. Edge JA, Roy Y, Bergomi A, Murphy NP, Ford-Adams ME, et al. (2006) Conscious kevel in children with diabetic ketoacidosis is related to severity of acidosis and not to blood glucose concentration. Pediatric Diabetes 7: 11-15. [Crossref]

10. Nyenwe EA, Khan EA, Razavi AE,Wan JY, Kitabchi AE (2010) Acidosis: The Prime Determinant of Depressed Sensorium in Diabetic Ketoacidosis. Diabetes Care 33: 1837-1839. [Crossref] 
11. Niwa T (1995) Mass spectrometry in diabetes mellitus. Clinica Chimica Acta 1412: 190-220. [Crossref]

12. Vernon DD, Postellon DC (1986) Nonketotic hyperosmolal diabetic coma in a child: management with low-dose insulin infusion and intracranial pressure monitoring. Pediatrics 77: 770-772.

13. Umpierrez GE, Kelly JP, Navarreete JE, Casals MM, Kitabchi AE (1997) Hyperglycemic crises in urban blacks. Archives of Internal Medicine 157: 669-675. [Crossref] 